Developing children: developmental discourses underpinning physical education at three Scottish preschool settings

Nollaig McEvilly ${ }^{\mathrm{a}^{*}}$, Matthew Atencio ${ }^{\mathrm{b}}$ and Martine Verheul ${ }^{\mathrm{c}}$

${ }^{a}$ Department of Sport and Exercise Sciences, University of Chester, UK; ${ }^{b}$ Department of Kinesiology, California State University, East Bay, USA; 'Institute for Sport, Physical Education and Health Sciences, The University of Edinburgh, UK

*Corresponding author. Department of Sport and Exercise Sciences, University of Chester, Parkgate Road, Chester, CH1 4BJ, UK. Email: n.mcevilly@chester.ac.uk 


\section{Developing children: developmental discourses underpinning physical education at three Scottish preschool settings}

This paper reports on one aspect of a study that investigated the place and meaning of 'physical education' to practitioners and children at three preschool settings in Scotland. We employed a poststructural type of discourse analysis to examine the developmental discourses the 14 participating practitioners drew on when talking about 'physical education' at preschools, during semi-structured interviews. Three main discourses around the notion of developmentalism were identified during analysis of the adults' interview data: (1) preschool children learn and develop through play; (2) preschool children should have choices and freedom; and (3) sometimes more structured activities are needed. The practitioners were heavily invested in developmental 'truths' about how preschool children learn and develop. They were in agreement that play is a vital element of preschool education, and that, consequently, children should be provided with opportunities for exploration and making choices. However, they also talked about sometimes 'needing' to restrict children's freedom and provide more adult-led activities. Our findings illustrate the strength of developmental discourses at the three settings. We suggest that preschool practitioners, as well as policy-makers and researchers, should critically reflect on the effects of taken-forgranted developmental discourses, and move beyond thinking in terms of binaries such as 'physical education versus play' or 'structure versus freedom'.

Keywords: Developmental discourses; Physical education; Preschool; Scotland; Foucault.

\section{Introduction}

This paper reports on one aspect of a study that investigated the place and meaning of 'physical education' to practitioners and children at three preschool' settings in Scotland. Underpinned by a poststructural, Foucaultian theoretical framework, the study examined the discourses of physical education at the preschools,

\footnotetext{
${ }^{1}$ In Scotland, children are entitled to free part-time preschool education from the term after their third birthdays (The City of Edinburgh Council, 2015). They usually start primary school when aged four or five years (Education Scotland, 2015). As such, in this paper, 'preschool' refers to children's educational experiences before they begin formal schooling (i.e. when they are generally aged three to five years).
} 
and interrogated the ways in which the participants engaged with them. In this paper, we examine the developmental discourses the adult participants drew on. By focusing on preschool practitioners, the study provides insight into 'what happens' in relation to physical education at three preschool contexts. It allows us to explore the reasons particular discourses and practices may be taken up or resisted, and to illustrate the workings of discourses that may be taken for granted (MacLure, 2003). We argue that interrogating taken-for-granted assumptions and practices is a vital element of the quest to provide positive and inclusive physical education experiences for preschool children.

\section{Background}

While a growing body of research is concerned with preschool physical activity, it seems that preschool physical education (i.e. planned, organised physical learning experiences in curricular time) has been largely unexplored by scholars. A small number of studies on preschool physical education have emerged in recent years (e.g. Hastie, Rudisill, \& Boyd, 2015; Tsangaridou \& Genethliou, 2014), along with some others (e.g. Marsden \& Weston, 2007) that are concerned with early childhood education more widely than preschool (i.e. also focusing on children in the early years of primary school). The apparent lack of research may be due to the fact that preschool curricular frameworks tend not to be split up into individual subjects, but according to broader areas of development (Stephen, 2006). In England, for example, the Early Years Foundation Stage framework has three key areas, one of which is physical development (Stirrup, Duncombe, \& Sandford, 2015). Until recently, the Scottish preschool curriculum featured a similar category and thus similar language; the previous preschool curriculum in Scotland (Learning and 
Teaching Scotland (LTS), 2004) referred to 'physical development and movement'. However, the current curriculum - Curriculum for Excellence (LTS, 2009) specifically refers to 'physical education' in relation to preschool education. This is perhaps because Curriculum for Excellence is a single curriculum for three- to 18year-olds; it applies to education in Scotland from preschool right through to the end of secondary education. This change in language provides us with a compelling context for our study, since examining patterns in language is the focus of our poststructural analysis.

From a poststructural perspective, knowledge and its construction are contextspecific and value-laden (Dahlberg, Moss, \& Pence, 2007). As such, knowledge is considered to be 'full of contradictions, unanswered questions and cultural prejudices' (Danaher, Schirato, \& Webb, 2007, p. 2). Poststructuralism, then, is concerned with thinking 'against the grain' (Deegan, 2004, p. 226) of dominant discourses.

Discourses are sets of truths that are (re)produced through power relations and social practices operating in institutions, such as prisons, schools or, in this case, preschools (Foucault, 1973). Techniques of power (e.g. disciplining individuals and exercising surveillance) operate in institutions to produce and constrain particular actions and practices (Evans \& Davies, 2004). Poststructuralism is concerned with understanding how power relations operate to privilege certain practices and subjectivities (Wright, 2006). Many previous poststructural studies in physical education and related areas including physical activity and health have focused on secondary school students or adults (e.g. O’Flynn, 2010), while researchers including Burrows (e.g. 2010) have conducted similar research with primary school children. We aim to extend this scholarship by drawing on the poststructural concepts of discourse and power to investigate preschool physical education. Our aim is to examine how developmental 
discourses that are prevalent throughout the literature related to early childhood education might influence preschool physical education provision.

As noted above, early childhood curricular frameworks tend to be structured according to areas of development. It is not surprising, then, to see that developmental discourses are prevalent throughout the early childhood education field. Dahlberg et al. (2007) note that developmental psychology has come to play a dominant role in pedagogical practice. As Walkerdine (1998, p. 162) observes, 'the common sense of child development...is everywhere [in education], in apparatuses from teachertraining, to work-cards, to classroom layout'. Developmental psychology is concerned with determining 'universally applicable, factual and correct statements about how children develop' (MacNaughton, 2005, p. 23). Developmentalism is a term used to refer to these types of statements and the assumptions underpinning them (Burrows, 2004).

The dominance of developmental psychology, particularly because of 'Developmentally Appropriate Practice' (Bredekamp, 1987; Bredekamp \& Copple, 1997), is such that it has been difficult to think about young children from outside of it (Prout \& James, 1997). Jean Piaget's (1896-1980) work, in particular, has dominated understandings of childhood and learning (Robinson \& Jones Díaz, 2006). According to Piaget's theory of cognitive development, children reach developmental stages in a linear process correlating with age (Robinson \& Jones Díaz, 2006). Piaget's work 'gave play, particularly in the early years, its distinctive authority as a basis for the evolution of learning' (Jones, Hodson \& Napier, 2005, p. 44). His scholarship emphasises child-centredness and active learning, characterising children as problemsolvers who learn by exploration (Burman, 2008). The Scottish Executive (2007) connects active learning to concepts including play, exploration, child-centredness 
and fun, while Plowman and Stephen (2005) maintain that play is the primary vehicle for learning in preschool education in Scotland. Furthermore, McEvilly (2014) observes that developmental discourses are prevalent throughout the aforementioned Scottish curricular documentation related to preschool physical education. McEvilly's analysis shows that, despite the change from 'physical development and movement' to 'physical education' in the curriculum, developmental discourses are still dominant.

Literature that is critical of the dominance of developmental discourses is evident in both early childhood education and physical education scholarship. They have been criticised for assuming universality and therefore encouraging comparisons and judgements (Burman, 2008; Burrows, 2004). Burrows and Wright (2001) argue that developmental discourses have 'normative and exclusionary tendencies' (p. 179), which can lead to some children being labelled as 'developmentally delayed' or 'immature' (Burrows, 2004). Assumptions about 'normal' development vary, however, because developmental stages are social and cultural constructions (Burrows, 2004) and what is viewed as a 'normal' childhood is culturally and temporally specific (Baker, 1995). As such, rather than viewing childhood as an innate phase in human development, universally experienced by all, critical scholars argue that it is 'a social construction - a social process in which understandings of what it means to be a child are constituted within the historical and cultural discourses available' (Robinson \& Jones Díaz, 2006, p. 6). In addition, developmental discourses have been criticised for implying that children are merely adults-in-training (Sorin, 2005) and are therefore 'becomings' rather than 'beings' (Woodrow \& Press, 2007). Characterising children in this way denies their competence and agency (Woodrow \& Press, 2007). 
The research outlined above illustrates how developmental discourses can influence assumptions about child development, based on age. Following on, we examine how developmental discourses influence preschool physical education at three preschool settings in Scotland, and whether practitioners have specific expectations regarding the experiences preschool children 'should' have. As such, our study investigated how the participating preschool practitioners engaged with the notion of preschool physical education, in relation to developmental discourses that position preschoolers in particular ways. Previous research indicates that preschool practitioners perceive their role as being 'facilitators', rather than 'teachers' (Moyles, Adams, \& Musgrove, 2002; Stephen, 2005). Consequently, we investigated how the participating practitioners engaged with discourses around play and learning, and how they perceived their roles during 'physical education'.

\section{Methodology}

The study was approved by the ethics committee of The Moray House School of Education, The University of Edinburgh. We employed a poststructural type of discourse analysis concerned with examining patterns in language (Wright, 2004), focusing on the discourses of physical education within three preschools. The lead author conducted the fieldwork from March 2010 until January 2011. The preschools (referred to by the pseudonyms of Oakdale, Cheery Faces and Sunnyland) were purposefully selected. They differed in size and socio-economic status (SES) (see Table 1), as well as in terms of the practitioners' experiences of continuing professional development (CPD) related to preschool physical education. At Oakdale,

\footnotetext{
${ }^{2}$ We use quotation marks because 'physical education' was a term most participants did not use in relation to preschool contexts. 'Physical education' (in quotation marks) refers to any physical activities, physical play and movement experiences at the preschools.
} 
two practitioners (Amanda and Tanya) had engaged in a three-part Early Moves ${ }^{3}$ CPD course (one day and two evenings). The practitioners at Cheery Faces had participated in a one-day Early Moves course. Those at Sunnyland had not participated in any physical education CPD. Another difference between the preschools was that the children at Oakdale experienced a weekly physical education lesson in the school gym hall with Tanya, a physical education teacher.

'Insert Table 1 here'

The lead author engaged in participant observation and held interviews with practitioners and children. The current paper focuses on the interview data generated with the adults. Fourteen adults participated; pseudonyms are used for anonymity. Most adult interviews featured one participant, but four practitioners asked to be interviewed in pairs. Table 2 outlines the practitioners' roles, backgrounds in terms of training and qualifications, and the number of interviews they participated in. The 14 women's backgrounds highlight the diverse range of training and qualifications people working in early childhood care and education may undertake (Moyles et al., 2002; Siraj-Blatchford, 1999).

'Insert Table 2 here'

Interviews were semi-structured, combining features of formal interviews (interview schedule) with features of unstructured, conversational interviews (openended questions) (Willig, 2003). In their initial interviews, practitioners were asked

\footnotetext{
${ }^{3}$ Early Moves is 'a developmentally appropriate movement framework for young children' (Jess \& McIntyre, 2009, p. 16). It was constructed and is promoted through CPD courses by the Developmental Physical Education Group (DPEG) at The University of Edinburgh.
} 
about their roles and backgrounds, and to discuss what happened in relation to 'physical education' at the preschools. Subsequent interviews followed up on discussions about the term 'physical education' during the first interviews, and featured questions specifically related to developmental discourses, which the observations and earlier interviews indicated were prevalent in 'physical education' at the settings. For example, the women were asked to discuss what play meant to them, and to describe its place in preschool education.

Interviews were transcribed and interpreted as discursive texts, as were the field-notes. Drawing on MacLure's (2003) guidelines, we constructed analytical questions to interrogate the data. The analysis reported in this paper probes around four analytical questions: (1) what developmental discourses do the participants draw on when talking about 'physical education'?; (2) what developmental 'truths' and meanings are constructed and privileged?; (3) how are knowledge claims related to these developmental discourses established and defended?; and (4) what are possible consequences for practitioners' and children's practices and subjectivities? We engaged in 'close reading' (Burrows, 2010, p. 239) of the texts in order to investigate our analytical questions.

We drew on Foucault's work (e.g. 1991) to understand how the discourses we identified reflected the operation of power, referring in particular to the eight techniques of power outlined by Gore (1995). Numerous studies concerned with power in education (e.g. Webb \& Macdonald, 2007; Wrench \& Garrett, 2008) have utilised Gore's (1995) framework of the major techniques of power, which she devised based on her argument that 'the techniques of power which Foucault elaborated in prisons [are also] applicable to contemporary pedagogical practice' ( $\mathrm{p}$. 
168). The eight techniques of power presented in Gore's (1995, p. 169-180) framework are:

- Surveillance (observing, supervising, watching, threatening to watch, expecting to be watched)

- Normalisation (defining what is normal - invoking, requiring, setting or conforming to certain standards)

- Exclusion (the opposite of normalisation - defining what is pathological)

- Classification (differentiating individuals or groups from one another ranking and categorising)

- Distribution (how bodies are arranged in space - for example, how they are isolated or separated)

- Individualisation (giving individual character to oneself or someone else)

- Totalisation (specifying collectivities, giving collective character, constructing or addressing groups)

- Regulation (controlling by rules, restrictions, sanctions, rewards and punishments).

Since discourses are instruments and effects of power (Foucault, 1998), Gore's framework helps to explain how discourses operate. As such, interrogating the data for techniques of power allowed us to investigate how particular developmental 'truths' and practices operated within the preschools.

\section{Findings and discussion}

Three main discourses reflecting the concept of developmentalism were identified during analysis of the adults' interview data: (1) preschool children learn 
and develop through play; (2) preschool children should have choices and freedom; and (3) sometimes more structured activities are needed. We now focus on the practitioners' commentary in order to illustrate how these sets of 'truths' influenced the provision of preschool physical education.

\section{Discourse 1: preschool children learn and develop through play}

The practitioners considered play to be an integral element of early childhood education, and all connected it to learning and development. For instance, according to Amanda (Oakdale, teacher), play involved 'children learning, developing, experimenting, trying new things through a range of different activities and media'. Many of the practitioners' comments reflected the Piagetian characterisation of learning as a linear process that corresponds with cognitive developmental stages. This perspective dovetails with the concept of active learning, whereby children are positioned as systematically seeking out and solving problems. The practitioners' responses, when asked about play, included:

...they are exploring themselves all the time and they're finding out, they're using their own mind. [...] ...I'm not telling them what to do, so they've got to use their own brain and work things out for themselves. (Jean, Sunnyland, manager)

...everything's through play, absolutely everything is fun through play. [...] You know, it's active learners - that's the key word. [...] Mmm, but they have to explore. [...] If they don't explore themselves, they're not going to actually find out. (Ivy, Sunnyland, nursery nurse) 
Normalisation, whereby particular standards are invoked, set and expected to be adhered to (Gore, 1995), is evident in how Jean and Ivy talked about what learning through play involves (e.g. exploring and actively learning). Speaking with certainty about what children 'have to' do, they characterised play as imperative. Gore (1995) describes exclusion as a technique of power involving the construction of pathology or non-normativity. Exclusion is evident within the women's references to what learning through play does not involve (e.g. adults telling children what to do). Both women also engaged in totalisation, whereby collectives are defined in particular ways (Gore, 1995), such as through Ivy's reference to 'active learners'.

Four other practitioners also mentioned the notion of active learning. Other direct references to Piagetian concepts included Annie's comment that preschool children are 'egocentric... because of their developmental stage' and her contention that they find 'abstract concepts...very difficult to understand' (Annie, Sunnyland, nursery nurse). Engaging in normalisation, totalisation and classification, Annie drew on a deficit view of children based on their particular developmental stage. Classification involves what Foucault (1982) terms 'dividing practices' (p. 777) that are used to distinguish (and therefore exclude) certain individuals or groups based on distinctions of normality and pathologism. Annie's remarks reflect the focus in developmental psychology on 'dividing' or classifying children according to normalising ages and stages (Dahlberg et al., 2007).

These comments by the practitioners demonstrate how developmental assumptions influence people's views of what children can and cannot do at particular ages (Burrows, 2004). While many of the practitioners' references to children's ages involved practices of classification, Rachel engaged with developmental discourses in 
a different way when asked about important things to consider when planning preschool physical education CPD courses or resources. While Rachel initially mentioned preschoolers' potentially limited attention spans, she subsequently emphasised that this was not a taken-for-granted assumption for her:

And some of the children get....are so focused. [...] It's just, I don't think there's much different; they're pretty capable at three-and-a-half, the children, really. It's just about making sure the level was appropriate, I suppose, and the challenge. (Rachel, Cheery Faces, manager/owner)

Rachel drew on developmental discourses in multiple ways; although mentioning the importance of 'making sure the level was appropriate', she talked about preschoolers' capabilities and maintained they are not significantly different from older children. Her assertion that some preschoolers can be 'focused' during their physical activities contrasts with the prevailing developmental discourses reproduced by the cohort. That is, Rachel's comments do not only speak to the children's perceived lack of attention spans and abilities to concentrate.

In sum, all of the participating practitioners aligned with the view that play is fundamental to learning and development. In the next section, we further discuss this finding and its implications for the type of support the practitioners gave to the children. They explained that it meant giving preschool children opportunities to be 'free' and to make choices, and that they did not view themselves as 'teachers' in an explicit sense.

Discourse 2: preschool children should have choices and freedom 
The comments below illustrate how the practitioners emphasised the importance of children having choices and freedom in their activities. This concern appeared to stem from their belief that children learn and develop through play. Choices and freedom were concepts many practitioners mentioned when asked about the notion of play. Vanessa (Cheery Faces, nursery nurse), for instance, stated that play involved children 'choosing what they want to do'. According to Stacey (Oakdale, teacher), 'anything that they choose to do using the resources around them is play'. Jessica, Ivy and Annie, all nursery nurses at Sunnyland, along with Amanda (Oakdale, teacher) and Serena (Cheery Faces, nursery nurse), all talked about play in terms of fun and enjoyment.

The perspective of play described above also came to influence how the practitioners envisioned their roles in the learning process. In the extended exchange below, Serena and Vanessa stressed the importance of staying in the background during children's physical play:

SERENA: I mean I feel I do sometimes take a step back, but maybe if I see that someone is just sitting around, I will try and encourage them to do something. But generally just supervising, isn't it?

VANESSA: They don't want you to join in sometimes either.

SERENA: Uh-huh.

VANESSA: They're just like, nah.

SERENA: Obviously if we're needed, then we will step in, but just, kind of, let them do what they want to do.

VANESSA: And you don't want to make it, like, too structured either. Like, 'Right, we're going to...' 
SERENA: Because there is a lot of structure throughout the day, so it is good for them just to choose what they want to do.

VANESSA: Without an adult, like, interrupting and saying, 'Do it this way'. (Serena and Vanessa, Cheery Faces, nursery nurses)

Serena and Vanessa constructed free play (i.e. child-led) in opposition to structured activities (i.e. adult-led). Serena's reference to 'a lot of structure throughout the day' indicates that the children's time outdoors was a chance to have a break from the more structured indoor environment; Serena and Vanessa appeared to have different expectations regarding indoor and outdoor spaces. Their talk supports the research of Maynard, Waters and Clement (2013), who found that early childhood teachers allowed children more opportunities to engage in free play outdoors than indoors. Maynard et al. report that practitioners had less rigid expectations regarding children's behaviour in the outdoor environment; outdoor spaces were positioned as arenas in which children had more freedom from adult control compared to indoor spaces. Serena's and Vanessa's talk illustrated how an emphasis on children's choice-making and freedom influenced their pedagogical practices (leading them to primarily 'supervise' rather than intervene and tell the children to 'do it this way').

While 'physical education' at each setting featured - to varying degrees - both child-led free play and more adult-led activities, the women were generally in agreement that their roles as preschool practitioners did not involve 'teaching' children in a formal, direct way. Tanya - the physical education teacher at Oakdale explained that her role with the preschoolers was different from her role with older children: 
I think in nursery there's a lot more of, 'Let's go and try this' ... and they come up with various different options of getting there and there's not really...like, the primary children get to do that as well, but there's...nursery, there's not really rights and wrongs because a lot of it's so generic. [...] Whereas in upper primary, say you're playing a game, it has quite a specific goal, so everything has to work. You know, it's a lot more guided learning. [...] Whereas I think nursery...in fact, probably nursery's more open-ended, that's probably...the, kind of, word for it. (Tanya, Oakdale, physical education teacher)

Tanya's comments reveal that, although she led the lessons, they featured more exploratory, 'open-ended' activities than lessons with older children. Her reference to 'rights and wrongs' positions physical education with older children as concerned with learning 'correct' skills and knowledge; this conception of physical education in primary and secondary education has indeed been revealed as dominant, according to Atencio, Chow, Tan, and Lee (2014). These authors remind us that traditional pedagogies in physical education are often structured according to "a more "closed" technical movement perspective undergirded by notions of mature movement acquisition' (p. 260). In this case, Tanya's commentary diverges from the dominant model of physical education. She claims that this is not the way forward with preschoolers, where the focus should be on 'trying' and experimenting. Tanya explained that she struggled with this pedagogical approach when she first taught preschool children:

...I hated it. It was, like, I dreaded it because I just felt as if I didn't know what to do with them. [...] ...I didn't know what to expect from the children and, 
like, the discipline and things, I didn't know what was okay to let them do and what wasn't and if they didn't do what I asked them to do, I wasn't really sure how to deal with it. [...] Just totally out of my comfort zone, you know, is probably what it came down to. (Tanya, Oakdale, physical education teacher)

Tanya's comments show the extent to which she valued developmental 'truths'. Initially, she felt that she lacked 'knowledge' about what preschoolers 'should' and 'should not' do. She found it difficult to adapt her teaching practices, assuming they were appropriate for older children (and thus inappropriate for younger children). By contrasting older and younger children, Tanya engaged in the practice of classification. Her perceived lack of 'knowledge' led to feelings of insecurity and worry; Tanya worried that preschoolers would not be 'able' to take instruction in the same way as older children, and so felt confused and perhaps less in control than she was accustomed to being during lessons with older children. Tanya's final comment regarding being 'totally out of my comfort zone' resonates with contemporary descriptions of pedagogy that approaches the 'edge of chaos' (Jess, Atencio \& Thorburn, 2011). From this perspective, the process of struggling over one's pedagogical approach by experimenting with new practices can be viewed as productive to practitioners' development as well as children's learning (Light, 2012). Tanya was not the only practitioner to talk of pedagogical dilemmas related to 'physical education' for preschoolers. For some of the women, their privileging of choices and freedom clashed with the very notion of 'physical education'. They tended not to use the term 'physical education', as they generally considered it to be a concept more associated with schools than preschools (see McEvilly, Verheul, \& Atencio (2015) for a detailed discussion of this finding). Many of them positioned 
'physical education' as something more structured than what children would (or 'should') experience at preschool. Jessica (Sunnyland, nursery nurse) and Alison (Oakdale, nursery nurse) indicated that the 'problem' with the term 'physical education' in relation to preschools may be the word 'education'. Jessica explained that she associated 'education' with something more formal or structured than she, as a preschool practitioner, was comfortable with. She positioned 'physical education' in opposition to preschool education, which she described as 'relaxed' and 'freeflowing'. Similarly, Alison (Oakdale, nursery nurse) constructed a binary between preschool education, which she claimed is concerned with play, and schooling, which focuses on education. Both Jessica's and Alison's commentary supports the scholarship of Moyles et al. (2002), which indicates that some early childhood practitioners are uncomfortable with words such as 'teaching', because they regard themselves as 'facilitators' rather than 'teachers'. Comments from many of the other practitioners also corresponded with this research, as they too expressed discomfort with the term 'physical education', similarly indicating that it evoked images of something more formal or structured than they felt was appropriate for preschoolers. In contrast to traditional identities found in primary and secondary physical education underpinned by active intervention in order to achieve pre-set learning outcomes (Jess et al., 2011), many of the preschool practitioners here agreed that their roles in 'physical education' were generally to observe and supervise. Comments included:

It's really observing a lot more outside than joining in really, unless they want you to. (Dawn, Oakdale, learning assistant) 
...generally it's just supervising and putting out the different activities for them and changing things around. (Jessica, Sunnyland, nursery nurse)

More observing - you, kind of, observe their play because you don't want them to play any, like, fighting games or anything like that. (Naomi, Sunnyland, nursery nurse)

Yet, while the practitioners' comments seemingly diverge from more authoritarian and linear pedagogical practices often found within physical education, the emphasis they placed on observation showed that surveillance was a technique of power that was particularly evident at the preschools. Their comments show that, while the women may have had benevolent intentions (e.g. ensuring children's safety), surveillance was a key means of regulating the children (Ailwood, 2003) and assessing whether they conformed to particular standards (Dahlberg et al., 2007). The practitioners enacted disciplinary power in a way that aligns with how Foucault (1991) contends that it operates - through hierarchical observation and normalising judgement. Naomi's comment above shows how surveillance was a technology of regulation; practitioners watched the children to ensure they behaved in a certain way. Evoking images of Bentham's conceptualisation of the panopticon (Foucault, 1991), adult surveillance served as a means of encouraging children to self-regulate.

Furthermore, the practitioners made many comments about assessing children's skills, showing how surveillance also operated as a means of classifying them according to certain standards. For instance, Jessica (Sunnyland, nursery nurse) talked about observing children in order to assess their running, hopping, skipping, balancing and ball skills. This notion of assessing skills appears to contradict the idea, 
discussed earlier, that preschool education is not concerned with 'rights and wrongs' (Tanya, Oakdale, physical education teacher). Many other practitioners made similar comments to Jessica. They talked about their pedagogical practices being based on these observations, which they claimed enabled them to ascertain what the children's 'needs' were. References to 'child-led' planning and practice were based on the idea that children's 'needs' could be determined by adult surveillance and classification. Thus, while 'child-led practice' was a notion the women frequently alluded to, this

concept did not always mean children had actual choices or freedom; 'child-led' often reflected the operation of adult power, with practitioners deploying specific practices they deemed as necessary. As such, although the 'preschool children should have choices and freedom' discourse was strongly manifested in the women's talk, like all discourses it was taken up and reproduced in multiple ways. At times, choices and freedom were constructed as important for children, but at other times, the adults deemed it important for children to experience activities that were 'necessary' for their development.

\section{Discourse 3: sometimes more structured activities are needed}

The practitioners agreed that, despite their concern with children having choices and freedom, there were times when more structured, adult-led activities were needed. Some of the women expressed this view more strongly than others. For instance, at Cheery Faces, Sarah (nursery nurse) and Rachel (manager/owner) emphasised the importance of children experiencing adult-led physical activities as well as free play more strongly than Serena and Vanessa (nursery nurses) did. Rachel explained that adult-led activities were a means of providing children with opportunities they might avoid if always allowed to choose what to do. Sarah 
similarly discussed the benefits of adult-led 'physical education' for children who might otherwise choose not to participate. When asked about her role in more structured 'physical education', Sarah described herself as 'the ringmaster', a role that involved allowing children to have choices, but sometimes adopting a more direct pedagogical style in which she instructed them. Thus, the "preschool children should have choices and freedom' and 'sometimes more structured activities are needed' discourses came together in Sarah's talk. These discourses also intersected in many other practitioners' comments. Naomi (Sunnyland, nursery nurse), for instance, mentioned 'structured play', which she said involved directing children towards particular open-ended, exploratory activities.

Amanda (Oakdale, teacher) strongly expressed the view that play at preschool should be structured, stressing that her role was to take children's learning forward:

...it [play] needs to be structured, it needs to be guided, because children have that kind of free sense of, like, being unrestricted in play...children can have that in a structured...in an environment that has been previously designed and set out, I think. But if you just left a child in a room with a sand tray, there's only so much they can learn by themselves. You need adults to structure their play and to add things to it and to take it forward because a child's not going to make those steps by themselves, they need some...they need a stimulus to take their next steps in their learning and that's what...that's what you're there for as an adult in the nursery. (Amanda, Oakdale, teacher)

This excerpt depicts the power relations inherent in play at the preschools. While children may have felt 'free' in their activities, practitioners utilised techniques of 
power (e.g. distribution) to structure the environment in such a way as to produce and constrain particular experiences and actions (Evans \& Davies, 2004). Gore (1995, p. 176) contends that practices such as those outlined above reflect the exercise of adult power in learning situations in accordance with their 'capacity to make these distributional decisions'; indeed, she contends that the 'exercise of that capacity reinforce[s] teacher-student power relations'. Following on, these 'distributional decisions are made according to some group characteristic' (Gore, 1995, p. 176) - in this case, according to the grouping of preschool children, such that the adults exercise power more actively, while the children are rendered as docile or reactive despite the rhetoric of choice-making and freedom alluded to earlier.

Stacey (Oakdale, teacher) aligned with Amanda's assertion that it was vital to be concerned with taking children's learning forward. She said she sometimes found the emphasis on choices and freedom frustrating, as she felt there were occasions when children 'needed' more direct guidance:

...I plan the activities, but the children choose, so the children are a lot more in control of their own learning. [...] Which is good sometimes, but sometimes it's frustrating because, you know, the children who just like to do art might choose to stay in and never go outside and they never learn things. [...] And I'm like, you know, I want to make them come outside and force them to learn it because it's going to help them in the long run, you know, to learn this skill now. So sometimes I do find that a bit frustrating. (Stacey, Oakdale, teacher)

Stacey's comments support the literature that proposes that notions such as play and child-centredness - while often unquestioningly promoted - can be problematic in 
practice (e.g. Burman, 2008; Dahlberg et al., 2007). Burman (2008), for instance, suggests that practitioners often struggle to promote children's learning when they are expected not to intervene or 'interfere' in the process, but at the same time they are institutionally responsible for securing children's learning outcomes. This view can be seen in Stacey's candid admission that sometimes she wants 'to make them come outside and force them to learn'.

Not all the practitioners spoke about the 'necessity' of structured activities with the same degree of conviction as Rachel, Sarah, Amanda and Stacey. For instance, Ivy (Sunnyland, nursery nurse) spoke strongly in defence of free play. She talked about the importance of children learning 'naturally' and claimed that organised activities disrupted this process. Naomi, Alison, Dawn, Serena, Vanessa and Jessica were also inclined to speak more strongly in favour of free play than adult-led activities. As such, a pattern emerged in relation to the women's views and the positions they held. With the exceptions of Sarah and Annie, the women who were managers or qualified teachers (Rachel, Jean, Amanda, Tanya and Stacey) spoke more strongly about the importance of adult-led activities than those who were nursery nurses (Alison, Serena, Vanessa, Jessica, Naomi and Ivy) or in Dawn's case, a learning assistant. While all the women agreed that there were times when structured physical activities were justified, it seemed that those who were more highly qualified and/or in more powerful positions were more comfortable with sometimes 'teaching' rather than solely 'facilitating'. This disparity was particularly evident in Jean's talk about encouraging the practitioners at Sunnyland to take more proactive roles in the children's outdoor activities: 
...it's good for staff as well, keep them motivated, 'cause they think, 'Oh it's not just going down to the garden and standing and watching the children play'. It's going down to the garden and getting involved with the children and if you don't give...don't lead them, staff will stand about. It doesn't matter who they are, they're not going to go and run around the garden unless they really feel they have to. (Jean, Sunnyland, manager)

Jean engaged in totalisation by commenting that 'all' practitioners will just 'stand about' unless compelled to be more involved in children's physical activities. She engaged in classification by categorising managers and nursery nurses as separate groups. In this way, through a 'dividing practice' (Foucault, 1982), she illustrated her position of power over the other women; Jean engaged in surveillance of the practitioners, while they engaged in surveillance of the children. Thus, hierarchical observation and normalising judgments (Foucault, 1991) were key instruments of disciplinary power operating not just between adults and children, but also amongst the manager and the other practitioners. Foucault (1991) argues that this type of institutionalised examination practice serves to 'constitute the individual as effect and object of power, as effect and object of knowledge' (p. 204). In this case, the less senior practitioners were subject to distribution and classification practices due to the belief that they were potentially unmotivated and needed to actively lead the children's activities.

Rachel (manager/owner) similarly stated that she encouraged the practitioners at Cheery Faces to lead more structured outdoor physical activities, as she was not happy to see staff 'just standing with their hands in their pockets'. Thus, both preschool managers were concerned with practitioners actively teaching children, 
rather than stepping back and 'letting development happen'. Jean elaborated on this, explaining that children needed help with physical skills:

...if you just keep throwing balls at children and letting them lie around, they'll play with them, but they never actually get the skill of catching the ball, because they need an adult to do it with them. [...] And then once they've seen an adult do it, then they'll try it together, but you've got to show them that. They can't...you know, I think some people think they'll just think this up themselves - they won't, they have to be shown it. (Jean, Sunnyland, manager)

Another reason Jean wanted the practitioners to take more leading roles in 'physical education' related to children's behaviour; she explained that some boys fought during outdoor play, so more structured activities were 'necessary' to eliminate this 'bad' behaviour. Jean engaged in 'dividing practices' (Foucault, 1982) regarding boys and girls, and good and bad behaviour. Classification and exclusion worked to position structured activities as 'necessary'; too much freedom meant some children fought and hurt each other. Jean thus constructed structured 'physical education' as a technique of regulation. The outdoor space - despite often being characterised by practitioners as an environment in which children could be free - was here envisioned as a disciplinary space where children's bodies were subjected to regulation through adult power. Certain behaviours were deemed as 'inappropriate' and therefore had to be eliminated through adult intervention. Jessica, Naomi, Annie and Ivy (nursery nurses) similarly talked about the need to regulate 'bad behaviour' when asked about leading children's 'physical education' at Sunnyland, as did Vanessa and Serena at Cheery Faces. They explained that too much free play could lead to children being 
'wild' (Vanessa, Cheery Faces, nursery nurse) and 'running about crazy' (Serena,

Cheery Faces, nursery nurse). The practitioners thus positioned structured activities as a disciplinary mechanism to make children focus and calm down. 'Good' children were thus characterised as calm and focused - perhaps docile and easier to control.

The practitioners gave a variety of justifications for structured 'physical education'. For some, children needed guidance in order to learn and develop in 'physical education'. For others, structured 'physical education' was less about children's learning and development than about regulating their behaviour. Again, like all discourses, this one was taken up and engaged with in a variety of ways.

\section{Conclusion}

Our findings illustrate the strength of developmental discourses at three preschool settings in Scotland. Foucault's - and Gore's (1995) - work around power underpinned our investigation into how these 'truths' operated. Surveillance was particularly evident in practice, while normalisation, exclusion, totalisation and classification were prevalent in the participants' talk.

The practitioners were heavily invested in developmental 'truths' about how preschool children learn and develop. While they sometimes engaged with these 'truths' in different ways, they were in agreement that play is a vital element of preschool education, and that, consequently, children should be provided with opportunities for exploration and making choices. Investment in these developmental discourses meant observation was positioned as an essential pedagogical practice. While the practitioners may have considered that this meant they were providing children with freedom from adult control, an alternative reading is that they were engaging in surveillance. By judging children's 'needs' based on this surveillance, the 
practitioners' observations can be re-interpreted as a technology of regulation (Ailwood, 2003) and normalisation (Dahlberg et al., 2007).

The practitioners positioned play as a vehicle for learning and development. They spoke about structuring play; this involved utilising techniques of power in order to lead children in a particular direction. The practitioners also talked about sometimes 'needing' to restrict children's opportunities for choice-making and freedom and provide more adult-led activities. They talked about this in different ways; some were very much in favour of such activities at certain times, while others were less comfortable with them. Nursery nurses tended to speak more strongly in defence of free play.

The discourses identified during the analysis were closely interconnected in the participants' talk and practice. The notion that play is the most appropriate means of learning and development for preschoolers underpinned the "preschool children should have choices and freedom' discourse. This second discourse operated both in conjunction and in competition with the third discourse, 'sometimes more structured activities are needed'. Sometimes, the participants talked about 'physical education' involving elements of both (adult-led) structure and (child-led) freedom. At other times, they positioned these notions as clashing, with some practitioners expressing frustration regarding how to appropriately combine them.

Consulting with practitioners has allowed us to gain insight into preschool 'physical education'. This paper has shown the strength of developmental discourses operating within three preschool settings. Based on this key finding, we suggest that there is a need for researchers, policy-makers and practitioners to critically reflect on the effects of taken-for-granted developmental discourses. In this regard, Burrows $(1999$, p. iv) reminds us that these developmental discourses significantly impact 'the 
realm of practice', whereby 'discourses of "child development" construct particular subjectivities and power relations in schooling which normalise and exclude many children'. Within our study, these developmental discourses reified unhelpful binaries such as 'physical education versus play' or 'structure versus freedom'; these binaries were drawn on and reproduced in ways that positioned children and adults as either normal or deficient. Furthermore, the practitioners experienced pedagogical dilemmas and contradictions when they tried to negotiate and reproduce these competing discourses.

Burrows (1999, p. iv) argues that, despite the entrenchment of developmental discourses in physical education, "there are "spaces" or "conditions of possibility" opening up in new physical education syllabi which may enable teachers and students to experience and practise child development differently' (p. iv). The Scottish Curriculum for Excellence thus provides a context for re-envisioning the nature of preschool 'physical education'. As noted by Thorburn, Jess and Atencio (2011, p. 385), this new curriculum moves away from a specialist teaching model and ostensibly provides 'a de-cluttering of curriculum and a greater educational connectedness between 3 and 18 years, with a personalized and holistic range of experiences supporting pupils' learning and assessment' (p. 385). Yet, despite this call for broader and holistic learning outcomes, rather than the acquisition of specialist knowledge through direct transmission teaching, there is still evidence of significant developmental rhetoric when 'improved learning transfer is intended across the ages and stages of child development and between pre-school, primary and secondary schools (Scottish Executive 2004b)' (Thorburn et al., 2011, p. 385). Curriculum for Excellence is thus set up to prioritise developmental stages of learning even as it calls for a more integrated view of learning. Amidst this paradox, we argue that it is vital 
for researchers, policy-makers and practitioners to fill in the 'policy to practice' gaps with respect to the concept of 'physical education' in preschools. Given the comprehensive rather than specialist learning principles found in the new curriculum, to support four broad learning capacities ('successful learners', 'confident individuals', 'effective contributors' and 'responsible citizens'), this does not mean restricting children's opportunities to play freely or expecting them to engage in highly structured, adult-led, didactic lessons. We further suggest that future research should investigate the ways preschool children interpret the messages and practices associated with developmental discourses, in order to interrogate their effects on young children.

\section{Acknowledgements}

We would like to express sincere thanks to the practitioners and children at Oakdale, Cheery Faces and Sunnyland. Thanks also to Dr. Mike Jess and the Developmental Physical Education Group at The University of Edinburgh for funding and supporting the research. Finally, we are grateful to the anonymous reviewers and the editor, Professor John Evans, for their constructive feedback and helpful advice. 


\section{References}

Ailwood, J. (2003). Governing early childhood education through play. Contemporary Issues in Early Childhood, 4, 286-299. doi: 10.2304/ciec.2003.4.3.5

Atencio, M., Chow, J.Y., Tan, C.W.K.,\& Lee, C.Y.M. (2014). Using a complex and nonlinear pedagogical approach to design practical primary physical education lessons. European Physical Education Review, 20, 244-263. doi: $10.1177 / 1356336 \times 14524853$

Baker, B. (1995, November). Defining the 'child' in educational discourse: a history of the present. Paper presented at the Australian Association for Research in Education (AARE) conference, Hobart, Tasmania.

Bredekamp, S. (Ed.) (1987). Developmentally appropriate practices in early childhood programs serving children from birth through age 8 . Washington, DC: National Association for the Education of Young Children.

Bredekamp, S., \& Copple, C. (Eds.) (1997). Developmentally appropriate practice in early childhood programs (revised edition). Washington, DC: National Association for the Education of Young Children.

Burman, E. (2008). Deconstructing developmental psychology. Hove: Routledge.

Burrows, L. (1999). Developmental discourses in school physical education. (Unpublished doctoral dissertation). University of Wollongong, Australia.

Burrows, L. (2004). 'Developing' athletes. In T. Cassidy, R. Jones, \& P. Potrac, Understanding sports coaching: The social, cultural and pedagogical foundations of coaching practice (pp. 82-89). Abingdon: Routledge.

Burrows, L. (2010). 'Kiwi kids are Weet-Bix ${ }^{\mathrm{TM}}$ kids' - body matters in childhood. Sport, Education and Society, 15, 235-251. doi: $10.1080 / 13573321003683919$

Burrows, L., \& Wright, J. (2001). Developing children in New Zealand school physical education. Sport, Education and Society, 6, 165-182. doi: 10.1080/13573320120084254

Dahlberg, G., Moss, P., \& Pence, A. (2007). Beyond quality in early childhood education and care: Languages of evaluation. Abingdon: Routledge.

Danaher, G., Schirato, T., \& Webb, J. (2007). Understanding Foucault. London: SAGE.

Deegan, J. (2004). 'Intentionally or otherwise': children and diversity in statutory and policy discourses in Ireland.' In J. Deegan, D. Devine, \& A. Lodge (Eds.), Primary voices: Equality, diversity and childhood in Irish primary schools (pp. 225-244). Dublin: Institute of Public Administration.

Education Scotland. (2015). Primary: the primary school curriculum. Retrieved from http://www.educationscotland.gov.uk/parentzone/mychild/primary/

Evans, J., \& Davies, B. (2004). Sociology, the body and health in a risk society. In J. Evans, B. Davies, \& J. Wright (Eds.), Body knowledge and control: Studies in the sociology of physical education and health (pp. 35-51). Abingdon: Routledge.

Foucault, M. (1973). The birth of the clinic: An archaeology of medical perception. London: Tavistock.

Foucault, M. (1982). The subject and power. Critical Inquiry, 8, 777-795. 
Foucault, M. (1991). Discipline and punish: The birth of the prison. London: Penguin Books.

Foucault, M. (1998). The history of sexuality, volume 1: The will to knowledge. London: Penguin Books.

Gore, J.M. (1995). On the continuity of power relations in pedagogy. International Studies in Sociology of Education, 5, 165-188. doi: 10.1080/0962021950050203

Hastie, P.A, Rudisill, M.E., \& Boyd, K. (2015). An ecological analysis of a preschool mastery climate physical education programme. Physical Education and Sport Pedagogy. Advance online publication. doi: 10.1080/17408989.2015.1017454

Jess, M., \& McIntyre, J. (2009). Learning and development: physical education move on. Nursery World, 29 January: 16-17.

Jess, M., Atencio, M., \& Thorburn, M. (2011). Complexity theory: supporting curriculum and pedagogy developments in Scottish Physical Education. Sport, Education and Society, 16, 179-199. doi: 10.1080/13573322.2011.540424

Jones, L., Hodson, E., \& Napier, N. (2005). The politics of play. In L. Jones, R. Holmes \& J. Powell (Eds.), Early childhood studies: A multiprofessional perspective (pp. 40-51). Maidenhead: Open University Press.

Light, R. (2012). Game sense: Pedagogy for performance, participation and enjoyment. London: Routledge.

LTS. (2004). A curriculum framework for children 3-5. Retrieved from http://www.ltscotland.org.uk/Images/CF3to5 tcm4-115469.pdf

LTS. (2009). Curriculum for excellence. Retrieved from: http://www.ltscotland.org.uk/Images/all_experiences_outcomes tcm4539562.pdf

MacLure, M. (2003). Discourse in educational and social research. Buckingham: Open University Press.

MacNaughton, G. (2005). Doing Foucault in early childhood studies: Applying poststructural ideas. Abingdon: Routledge.

Marsden, E., \& Weston, C. (2007). Locating quality physical education in early years pedagogy. Sport, Education and Society, 12, 383-398. doi: 10.1080/13573320701600621

Maynard, T., Waters, J., \& Clement, J. (2013). Moving outdoors: further explorations of 'child-initiated' learning in the outdoor environment. Education 3-13, 41, 282-299. doi: 10.1080/03004279.2011.578750

McEvilly, N. (2014). Experiences and outcomes of preschool physical education: an analysis of developmental discourses in Scottish curricular documentation. Contemporary Issues in Early Childhood, 15, 29-39. doi: 10.2304/ciec.2014.15.1.29

McEvilly, N., Verheul, M., \& Atencio, M. (2015). Physical education at preschools: the meaning of 'physical education' to practitioners at three preschool settings in Scotland. Physical Education and Sport Pedagogy, 20, 117-130. doi: 10.1080/17408989.2013.798407

Moyles, J., Adams, S., \& Musgrove, A. (2002). Early years practitioners' understanding of pedagogical effectiveness: defining and managing effective pedagogy, Education 3-13, 30, 9-18. doi: 10.1080/03004270285200291

O'Flynn, G. (2010). The business of 'bettering' students' lives: physical and health education and the production of social class subjectivities. Sport, 
Education and Society, 15, 431-445. doi:

$10.1080 / 13573322.2010 .514736$

Plowman, L., \& Stephen, C. (2005). Children, play, and computers in pre-school education. British Journal of Educational Technology, 36, 145-157. doi: $10.1111 / j .1467-8535.2005 .00449 . x$

Prout, A., \& James, A. (1997). A new paradigm for the sociology of childhood?: provenance, promise and problems. In A. James \& A. Prout (Eds.), Constructing and reconstructing childhood: Contemporary issues in the sociological study of childhood (pp. 7-33). London: Falmer Press.

Robinson, K.H., \& Jones Díaz, C. (2006). Diversity and difference in early childhood education. Maidenhead: Open University Press.

Scottish Executive. (2007). A curriculum for excellence: building the curriculum 2: active learning in the early years. Retrieved from http://www.educationscotland.gov.uk/images/Building the Curriculum_2 tc m4-408069.pdf

Siraj-Blatchford, I. (1999). Early childhood pedagogy: practice, principles and research. In P. Mortimore (Ed.), Understanding pedagogy and its impact on learning (pp. 20-45). London: Paul Chapman Publishing.

Sorin, R. (2005). Changing images of childhood - reconceptualising early childhood practice. International Journal of Transitions in Childhood, 1, 12-21.

Stephen, C. (2005). Submission to the Scottish parliament's education committee. Retrieved from http://archive.scottish.parliament.uk/business/committees/education/inquiries/e arly\%20years/Stephen_Dr_Christine.pdf

Stephen, C. (2006). Insight 28: early years education: perspectives from a review of the international literature. Retrieved from http://www.scotland.gov.uk/Resource/Doc/90566/0021792.pdf

Stirrup, J., Duncombe, R., \& Sandford, R. (2015). 'Intensive mothering' in the early years: the cultivation and consolidation of (physical) capital. Sport, Education and Society, 20, 89-106. doi: 10.1080/13573322.2014.941797

The City of Edinburgh Council. (2015). Starting nursery. Retrieved from

http://www.edinburgh.gov.uk/info/20071/nurseries_and_childcare/28/starting nursery

Tsangaridou. N., \& Genethliou, N. (2014). Early childhood educators' experience of an alternative physical education model. European Early Childhood Education Research Journal. Advance online publication. doi: 10.1080/1350293X.2014.970852

Thorburn, M., Jess, M. \& Atencio, M. (2011). Thinking differently about curriculum: analysing the potential contribution of physical education as part of 'health and wellbeing' during a time of revised curriculum ambitions in Scotland. Physical Education and Sport Pedagogy, 16, 383-398. doi: 10.1080/17408989.2011.557653

Walkerdine, V. (1998). Developmental psychology and the child-centred pedagogy: the insertion of Piaget into early education. In J. Henriques, W. Hollway, C. Urwin, C. Venn, \& V. Walkerdine (Eds.), Changing the subject: Psychology, social regulation and subjectivity (pp. 153-202). London: Routledge.

Webb, L.A., \& Macdonald, D. (2007). Techniques of power in physical education and the underrepresentation of women in leadership. Journal of Teaching in Physical Education, 26, 279-297. 
Willig, C. (2003). Introducing qualitative research in psychology: Adventures in theory and method. Maidenhead: Open University Press.

Woodrow, C., \& Press, F. (2007). (Re)Positioning the child in the policy/politics of early childhood. Educational Philosophy and Theory, 39, 312-325. doi: $10.1111 / \mathrm{j} .1469-5812.2007 .00328 . x$

Wrench, A., \& Garrett, R. (2008). Pleasure and pain: experiences of fitness testing. European Physical Education Review, 14, 325-346. doi: 10.1177/1356336X08095669

Wright, J. (2004). Post-structural methodologies: the body, schooling and health. In J. Evans, B. Davies, \& J. Wright (Eds.), Body knowledge and control: Studies in the sociology of physical education and health (pp. 19-31). London: Routledge.

Wright, J. (2006). Physical education research from postmodern, poststructural and postcolonial perspectives. In D. Kirk, D. Macdonald, \& M. O’Sullivan (Eds.), The handbook of physical education (pp. 59-75). London: SAGE. 
Table 1. Oakdale, Cheery Faces and Sunnyland - demographic information

\begin{tabular}{|c|c|c|c|c|c|}
\hline & Type of setting & $\begin{array}{c}\text { Location/ } \\
\text { SES }\end{array}$ & $\begin{array}{l}\text { Age of } \\
\text { children }\end{array}$ & $\begin{array}{c}\text { Number of } \\
\text { children }\end{array}$ & $\begin{array}{l}\text { Number of } \\
\text { practitioners }\end{array}$ \\
\hline Oakdale & $\begin{array}{l}\text { Attached to } \\
\text { primary school } \\
\text { (run by city } \\
\text { council) }\end{array}$ & $\begin{array}{c}\text { Urban } \\
\text { (low SES) }\end{array}$ & $\begin{array}{l}3-5 \\
\text { years }\end{array}$ & $\begin{array}{c}20 \text { in each of } \\
\text { two } \\
\text { preschool } \\
\text { classes }\end{array}$ & $\begin{array}{l}2 \text { (plus learning } \\
\text { assistant and } \\
\text { physical } \\
\text { education } \\
\text { teacher) }\end{array}$ \\
\hline $\begin{array}{l}\text { Cheery } \\
\text { Faces }\end{array}$ & $\begin{array}{l}\text { Partner-provider } \\
\text { (private; } \\
\text { preschool } \\
\text { education in } \\
\text { partnership with } \\
\text { city council) }\end{array}$ & $\begin{array}{c}\text { Suburban } \\
\text { (upper/ } \\
\text { middle } \\
\text { class) }\end{array}$ & $\begin{array}{c}6 \text { months } \\
-5^{1 / 2} \\
\text { years }\end{array}$ & $\begin{array}{l}75 \text { at a time } \\
\text { (130 on roll; } \\
35 \\
\text { preschoolers) }\end{array}$ & $\begin{array}{c}22(5 \text { in } \\
\text { preschool } \\
\text { rooms) }\end{array}$ \\
\hline $\begin{array}{l}\text { Sunny- } \\
\text { land }\end{array}$ & $\begin{array}{l}\text { Partner-provider } \\
\text { (owned by a } \\
\text { university; } \\
\text { preschool } \\
\text { education in } \\
\text { partnership with } \\
\text { city council) }\end{array}$ & $\begin{array}{l}\text { Urban } \\
\text { (mixed } \\
\text { SES, } \\
\text { mainly } \\
\text { middle } \\
\text { class) }\end{array}$ & $\begin{array}{c}2 \frac{1}{1 / 2}-5 \\
\text { years }\end{array}$ & $\begin{array}{l}24 \text { at a time } \\
\text { (37 on roll) }\end{array}$ & 5 \\
\hline
\end{tabular}


Table 2. Participating practitioners

\begin{tabular}{|c|c|c|c|c|}
\hline Setting & Practitioner & Job title & Qualifications & Interviews \\
\hline Oakdale & Amanda & $\begin{array}{c}\text { Teacher } \\
\text { (preschool until June 2010) }\end{array}$ & $\begin{aligned} &> \text { Bachelor of Science (BSc) (Outdoor } \\
& \text { Education with Environmental Science) } \\
&> \text { Postgraduate Diploma in Education } \\
&\end{aligned}$ & 3 \\
\hline Oakdale & Tanya & Physical education teacher & $\begin{array}{l}>\text { Bachelor of Education (Physical Education) } \\
>\text { Currently doing Postgraduate Certificate (3- } \\
14 \text { Physical Education) }\end{array}$ & 3 \\
\hline Oakdale & Alison & Nursery nurse* & $\begin{array}{ll}> & \text { National Certificate (NC) } \\
> & \text { Higher NC (HNC) } \\
> & \text { Personal Development Award (PDA) } \\
> & \text { Currently doing Bachelor of Arts (BA) } \\
& \text { (Childhood Practice) }\end{array}$ & $\begin{array}{c}3 \\
\text { (with Dawn) }\end{array}$ \\
\hline Oakdale & Dawn & Learning assistant & $\begin{array}{l}>\text { No qualifications necessary } \\
>\text { Qualified sick children's nurse }\end{array}$ & $\begin{array}{c}3 \\
\text { (with Alison) }\end{array}$ \\
\hline$\underline{\text { Oakdale }}$ & Stacey & $\begin{array}{c}\text { Teacher } \\
\text { (preschool from August 2010) }\end{array}$ & $\begin{array}{l}>\text { Master of Arts (Social Anthropology with } \\
\text { Development) } \\
>\text { Postgraduate Certificate in Education }\end{array}$ & 3 \\
\hline Cheery Faces & Vanessa & Nursery nurse & $>$ Scottish Vocational Qualification (SVQ) & $\begin{array}{c}3 \\
\text { (with Serena) } \\
\end{array}$ \\
\hline Cheery Faces & Serena & Nursery nurse & $>\mathrm{HNC}$ (Childcare and Education) & $\begin{array}{c}3 \\
\text { (with Vanessa) } \\
\end{array}$ \\
\hline Cheery Faces & Sarah & Nursery nurse & $\begin{array}{l}>\mathrm{NC} \\
>\text { Open Learning Level } 3\end{array}$ & 1 \\
\hline Cheery Faces & Rachel & Manager/owner & $>$ Qualified general nurse & 1 \\
\hline Sunnyland & Jean & Manager & $\begin{array}{l}>\text { Early Childhood Education Diploma } \\
>\text { Currently doing BA (Childhood Studies) }\end{array}$ & 3 \\
\hline Sunnyland & Jessica & Nursery nurse & $>$ National Nursery Examination Board & 3 \\
\hline
\end{tabular}




\begin{tabular}{|l|l|l|l|l|}
\hline & & & $>$ PDA (Childcare and Education) & \\
\hline Sunnyland & Naomi & Nursery nurse & $>$ HNC (Childcare and Education) & 3 \\
\hline Sunnyland & Ivy & Nursery nurse & $>$ HNC (Early Years and Childcare) & 3 \\
\hline Sunnyland & Annie & Nursery nurse & $>$ BSc (Honours) & 3 \\
& & & $>$ Registered general nurse & \\
& & & $>$ HNC (Childcare and Education) & \\
\hline
\end{tabular}

* Nursery nurse is a term commonly used in the UK to refer to a practitioner responsible for the care and education of preschool children. 